\title{
Migration Processes of Population in Durres District
}

\author{
Lindita Kiri \\ Phd Candidate, Lecturer at Aleksander Moisiu University, \\ Faculty of Business Durres, Albania
}

\section{Doi: 10.5901/mjss.2013.v4n4p277}

\section{Abstract}

\begin{abstract}
The fall of the communist regime caused major population movements. Starting in 1991 this phase matched with the period of transition and was characterized by a lack of policies regarding internal and international migration. During this period, as a result of changes in the country, control of movement of the population was removed and urban areas, especially Tirana and Durres, compared to rural areas, had a disproportionate development. There migrated approximately 900.000 people from rural to urban areas inside the country as well as to other countries. According to 2001 Census data this led to a declination of population in rural areas (13\%) compared to 1989 Census data, while in previous periods, population growth in rural areas had increased by $20 \%$ (INSTAT, 2012). From this data appears that Albania has been dominated by rural population, and in 2012 the entire rural domination reversed once dominated by rural urban population by 52\% (INSTAT, 2011), this is due to the free movement of people from rural to urban areas.
\end{abstract}

Key word: transition period, population migration, immigration.

\section{Introduction}

The immigration of the residents of Durres district couldn't be study only as a whole, because it has equally affected all Albanians immigration. This emigration during the 90s was one of the most dramatic demographic events observed in Europe and the study of migration movements took a great importance. Internal and international migration is characterized by different phases. Traditionally, Albania and the region of Durres is a country of emigration. In 15-17 centuries as a result of the occupation of Albania by the Turkish Empire, there was a mass emigration of Albanians across the coast in Italy. Later, during the first half of the 20th century, appear three migration periods: between 1912 and 1923 in the agricultural economy was ruined as a result of the First World War. In addition, the lack of industry and the misuse of natural resources affected the expatriation of 21000 Albanian families.

In the period from 1945 - 1989, the migration was in low levels. After 1990 we have increase of population migration in Durres District.

\section{Methodology}

For this paper I have used quantitative methods and qualitative methods and empirical data obtained from different sources. For this purpose, I have investigated and interviewed the population of the district Durres and have concluded as follows: population migration process Durres district after 90 years began and increased rapidly as a result of the economic and social consequences politic of the country. Was used the method of analysis and synthesis of the data. In this paper, I compared the process of migrating population of Durres district with other regions of the country. Finally, all parts in theoretical frame of reference and the empirical findings where analysed and conclusions where drawn.

\section{Historical overview on migratory movements (phases and aspects of migration)}

The immigration of the residents of Durres district couldn't be study only as a whole, because it has equally affected all Albanian immigration. This emigration during the 90 -s was one of the most dramatic demographic events observed in Europe and the study of migration movements took a great importance. For this reason, the description of the immigration and internal migration in Durres region is based on survey datas that represents a special interest. Internal and international migration is characterized by different phases. Traditionally, Albania and the region of Durres is a country of 
emigration. In 15-17 centuries as a result of the occupation of Albania by the Turkish Empire, there was a mass emigration of Albanians across the coast in Italy (INSTAT, 2004).

This period will be remembered for Durres as the capital of the Albanian state from 7 March 1914 to 1 February 1920. Durres became the capital of the Kingdom of Albania from Prince Wied when he disembark on 7 March 1914 till Congress of Lushnja dated February 11, 1920 for when Tirana was announced as the new capital on the Albanian state (Wikipedia, 2012, http://sq.wikipedia.org/wiki/Durr\%C3\%ABsi). As a capital Durres had an increase of population, but still difficult economic situation led to anemigration of the population in other more developed countries.

Between 1923 and 1939, economic backwardness and political uncertainty forced 110000 people to emigrate. During the period 1940-1945, emigrated approximately 19000 people, many of whom were political opponents of the communist regime comming in power.

With the establishment of the communist regime after World War II, in the period 1945 - 1989 was prohibited the emigration from Albania, while internal migration was limited and divided into several stages (Albanian People Progress Raport, 2000).

First phase (1950-1960) was characterized by the communist strategy of accelerating the development of the secondary sector (industry and construction), more than the third sector and internal migration from rural to urban areas, was controlled and directed but not totally prohibited. The second phase (1961-1990) was characterized by a limitation strategy of the internal migration from rural to urban, trying unsuccesfully the moving of the population from rural to urban areas. This isolation politics brought from the outside world the fell of the investment sources such as economic and social development process.

The fall of the communist regime caused major population movements. Starting in 1991 this phase matched with the period of transition and was characterised by a lack of policies regarding internal and international migration. During this period, as a result of changes in the country, movement control of the population was removed and urban areas, especially Tirana and Durres, compared to rural areas, had a disproportionate development. There migrated approximately 900.000 people from rural to urban areas inside the country as well as to other countries. According to 2001 Census data, this had a declination of population in rural areas such as (13\%), compared to 1989 Census data, while in previous periods, population grows in rural areas and increased by $20 \%$ (INSTAT Albania, 2012). From this data appears that Albania has been dominated by rural population, and in 2012 the entire rural domination reversed from rural, dominated in urban population by $52 \%$, this is due to the free movement of people from rural to urban areas (Registration of Population, INSTAT, 2011).

Moreover, international emigration of Albanians, but also the migration of the Durres region, mostly in western countries, and especially in Greece and Italy, is one of the most impressive migration during the 20th century in Europe. As a result of many factors, political, economic and social, at the end of 1990 were observed several phenomena that warned the migrant outbreak of Albanian cities. In July 1990, approximately 5.000 people entered in Italian, German and French embassies in Tirana and requested visa.

At the end of 1990, approximately 20.000 Albanians left the country toward Greece and asked for political asylum. In March 1991, more people entered the Albanian port of Durres, the largest one in Albania, in order to escape from Albania by boat. They arrived at the ports of southern Italy. Another shift that included about 18000 people occurred in the same year in August. Italian government categorically rejected them and within a short period, the majority of these emigrants returned to Albania. Undocumented immigration grew in the following years.

During the period 1989 - 2001, approximately 700000 Albanians left the country (Mbret et al., 1998; Bajraba et al 1992; Bajraba et Peronne, 1996). These migratory movements had an impact not only in the absolute number of the population and its geographical distribution, but also in the internal structure of the population (about reports of sex and age, as well as its socio-economic composition), and in the overall functioning of the economy and the country's infrastructure by defining the potential further development.

Migration also had a major impact on the economy as a factor that influences the trade balance (by transferring money within the country from abroad). It is difficult to make an accurate assessment of what has been the impact of internal migration and international migration, since there are other factors that also affected social and political activity of the economy.

Albanian emigration still continues and is in the period of transition from illegal and unorganized emigration into a legal and organized emigration (People Progress Raport for Albania, 2000). Albanian immigrants often work in sectors that are not preferred by the locals and the majority of them have undefinied salaries, they serve as a regulatory mechanism in the labor market and contribute to the growth of domestic production of the host country. However, the migration process has extensively involved the intellectual elite as well, which has some different features from those of different social groups who have emigrated. 
Recognition of the reality of migration is eventually an important element to formulate policies and to achieve social and economic development. Moreover, in the context of EU enlargement and the formulation of a European migration policy, migration from Albania, has become a priority because of the number of migrants and the geographical position of Albania (Registration of Population and residentials 2001, INSTAT 2004). If district of Durres is taken in a separate study, we will see that it has followed the same migration phase as the entire population of Albania.

The district of Durres has affected a positive increase of the region's population, bringing positive as well as negative consequences for the population. Durres district itself has specific areas where the number of population is high and other areas where the number of population is low, this is due to geographical factors, social, economic and cultural development occurring in the region of Durres.

\section{Internal migration, origin, size and typology of migration factors}

Internal migration in Durres region can be defined, based on two dimensions: Space dimension (migration between districts, towns, villages and municipalities of this region), and temporary migration (according to available data, migration from birth until the year 2012).

Some analyzes show clearly to a strong dependence between the short-term migration or the recent migration (2005-2012), term migration (2000 - 2004) and long-term migration during 1989 to 1999 . The migrant is defined as a person who has changed the community and residence between 1989 to 2012 (Registration of Population, INSTAT 2011). Some analyzes show a link between term migration and migration from birth until 2012.

Displacement of internal migration in Albania occurred not only among the prefectures, but also between regions of the same prefecture, between municipalities and between villages. Migration between prefectures was partly determined by the level of economic backwardness prefectures, from where was removed.

This removal was very emphatic in the district of Durres and still continues to be, especially the migration of Kruja district population to the cities of Tirana and Durres, but also the removal of the population from the region's of deep villages to more developed urban areas (Study of IOM and ILO, Thomas Kring, Geneve, 2007).

\subsection{The origin of migration}

So far there are no official data on migration, but the following chart shows the movement of the population of other 11 districts to Durres district until 2011.

Table: The number of newcomers from other counties in the district of Durres.

\begin{tabular}{cllllllllll}
\hline $\begin{array}{c}\text { Name of } \\
\text { district }\end{array}$ & Berat & Fier & Gjirokastër & Korcë & Vlorë & Elbasan & Tiranë & Dibër & Kukës & Lëzhë \\
\hline newcomers & 4241 & 2402 & 1817 & 3718 & 418 & 5191 & 3647 & 10997 & 6728 & 3390 \\
\hline
\end{tabular}

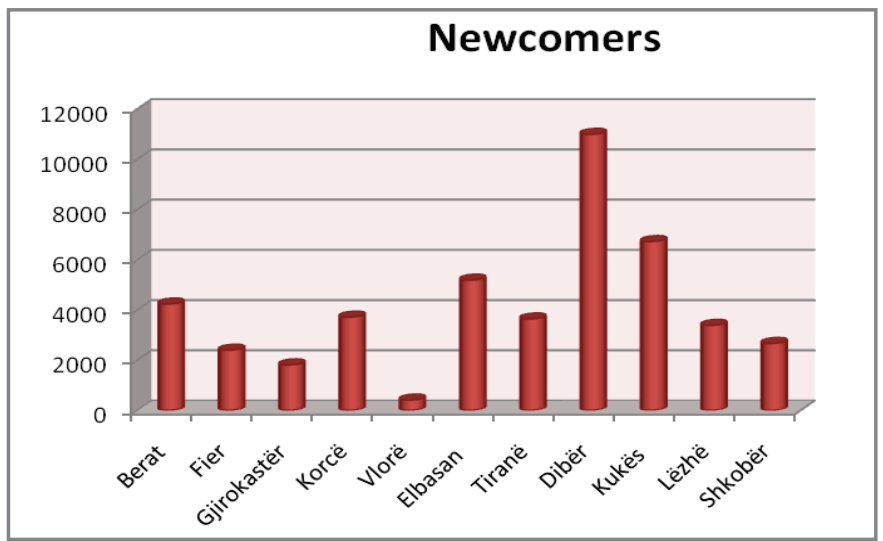

Graph: Graph of newcomers from other counties in the district of Durres (Author study). 
As the chart shows, most of the flow of immigrants comes from the northern districts of Albania, followed by migration from the South and a significant amount of the central districts of Albania. Referring to the cities, the highest number of migrants originates from Diber $(24.5 \%)$, while Kukes and Elbasan make together in total up to $51.1 \%$ (MATRA Programm, Durres Municipal study 2011, page 06).

Durres Region has the lowest level of migration that represents $7 \%$ of total migration. In relative value, the regions that had the highest number of the total migrating population are: first Diber, followed by Kukes, Elbasan and Berati. Regarding the host prefectures, Tirana is ranked the first, followed by the Durres, Fier and Vlora. $72 \%$ of the total number of migrants live in Tirana and Durres according to Census 2001, and the same values arise in the year 2011. Another important host region is Fieri, followed, in order of importance, from Vlora, Lezha and Elbasan (INSTAT Albania, Tirana 2012).

By analyzing the migration table from prefecture to prefecture during the period of 23 years 1989-2012, we distinguish two different types of migration: First, long-distance migration, directed to major economic poles in the center of the country; Second, migration in somewhat shorter distance in the direction of the coast, which is a region of emigration and migration (Study of Author).

Tirana consists of more than the half the displacement cross-prefecture between 1989-2012, over 226000 migrants coming from other prefectures. Durres is the second most attractive area after Tirana and has more than $18 \%$ of migrants with over 50000 .

Approximately 36.5\% (92 300) of migrants lived in the prefecture of Kukes and Diber in 1989; $70 \%$ of migrants from Kukes and Dibra went in Tirana and $20 \%$ in Durres. Another prefecture, that of Korca, in 1989 was the prefecture of $10 \%$ of the migrants who went to Tirana and $8 \%$ of those who went to Durres. Other regions had a low number of migrants who moved from prefecture to prefecture and within the region (INSTAT Identifications of migrations and emigrations zones in Albania, Profile of returned migrants, Tirana 2008).

This means that there was a homogeneous and dominant migrant community, with a special kind of solidarity that affects the development of the region.

The second type of migration is that of the near distance. In fact, a large number of poles located near the coast attract migrant population coming from the interior parts of the country and neighboring prefectures. This situation can be explained by several reasons; firstly, economic policy after the collapse of pyramid schemes in 1997 led most likely to decentralization. Second, there are likely to be returned to some of the displaced who after 1990 were located in different regions of the country for a better life and third return of emigrants from emigration's countries (The Readmission Agreement and the Labour Migration Agreement came into force on 1 August 1998. Foreigners who have held a permit for dependent or self-employment work, study or religious reasons for at least one year, or a residence card (art. 29) can apply for reunification with: a) spouse; b) dependent children; c) dependent parents. Parents over age sixty-five are allowed to enter under family reunion only if they can prove that no other child can provide for them in their native country; siblings and other relatives are not entitled to legal entry).

\section{Conclusions}

Some of the factors that have influenced the orientation of the newcomers toward urban centers of Durres district are: favorable geographical, transitional and strategic position of Durres district;

- major options of transport, trade and tourism development; the urban centers of the Durres region offer operation opportunities for more than 10.000 private enterprises (Informacion taken from Durres Municipal, 2011), mainly in trade sectors of (2429 employees, 404 transport employees, 660 tourism employees (Information taken from Ministry of Labour, Social Affairs and Equal Opportunities, Labour Office 2011);

- Economic development in general. Urban centers of the Durres district provide a favorable business climate by giving over $8 \%$ of the GDP of the entire country (Informtion taken from Ministry of Finance, 2012).

- Natural coastal offers great value for tourism, recreation and relaxation. The district of Durres has a long coastline, in which balnear tourism can be used very good. The region represents a source of cultural tourism, historical tourism, and rural tourism as well, as this region has the potential to be suitable for different types of tourism.

- Creation of the private sector and its rapid development, creating economic engine of this region, which in 2007 and today ranks second nationwide over $12.1 \%$ after Tirana, by the number of operating companies (Information taken from Ministry of Economics Trade and Energetic, Tirana 2012). 
- Important offers to employment and services. In this district are held numerous activities of trade and services, both in public and private sector. Non producing companies operating in the trade field have employed more than 2.500 employees; 660 in tourism, 404 in transport and 160 in construction (Information taken from Ministry of Labour, Social Affairs and Equal Opportunities, Labour Office 2012).

- $\quad$ an important social and cultural Offer.

Given that the positive balance of migration has played an important role in urban centers demographic growth in this region, in the service of maintaining stable growth rates of population, comens into being the need for migrant efficiency rating that expresses the necessity of intervention organization and control of spatial movements in one area, from a region in a region.

Internal migration to the region of Durres continues to grow rapidly today (2012). Internal migration in Durres region continues to grow on average of $1.7 \%$ per year. Demographic growth rate has declined, propelled by a more stable performance of the natural balance and the migrant. In addition, unlike previous periods, the process of emigration in the district of Durres is fading and feels more the role of the natural balance in demographic growth.

\section{Recommendations}

- Socio-economic situation analysis identified districts, communes, municipalities and households category and individuals who suffer the consequences of unemployment, lack of adequate social services, Educational and health services system problems. Economic poverty reduction and social exclusion achieved through the development of medium-and long-term policies which deepen respect for human rights, guarantee economic development, control internal migration as well as increase the efficiency of spending and public investment.

Economic development interventions must provide:

- Improvement of macroeconomic indicators that directly affect the well-being and poverty reduction,

- Develop regional policies that ensure the economic development of urban areas and rural areas, especially areas with high potential economic.

- Stimulating investments that develop agricultural economy and the private sector,

- Development of infrastructure as a important factor role in attracting foreign investors and facilitation of public services related to social protection, education and health interventions to improve public services in social protection system, Educational and health system, include:

- The design and implementation of strategies for poverty alleviation and protection of vulnerable categories,

- Increased public investment in social protection system, in Educational and health, as well as local government and community involvement in the financing and their implementation,

- Improve economic aid program to differential treatment of families various economic and social needs,

- Extension of active employment services and vocational training programs in rural areas,

- Development at Avatar and municipal social services for families and individuals in need

- Improvement of the territorial distribution of the school network and primary health centers, mainly in rural areas and congested areas

- Improve the physical condition of schools and health centers, as well as equipped with necessary tools for a service that respects basic human rights

- Improvement in school curricula, and teaching methods,

\section{Bibliography}

INSTAT, «labor market» 1990-1999

INSTAT, "Albania in Figures", 1997

INSTAT, "Albania in Figures", 2000

INSTAT, "Annual Social Indicators", 1999

INSTAT, Social indicators by region, 1998

INSTAT, and Social Security Protection System in Albania, 1996

INSTAT, Statistical Yearbook of Education, the December 1998

NICEF, "national study to cover vaccine", 1999

UNICEF, the rights of women and children, 1998

UNFPA, "Programme review and strategy development", 1997

World Bank, "Institutional and Capacity assessment of social services for vulnerable groups", 2000 
World Bank, Albania, "filling the Vulnerability Gap", Mansoura Rashid, Vajeera Dorabawila \& Richard Adams, July 1999

World Bank, Albania, "Household Welfare, the Labour market and public programs in Albania ", World Bank, July 1999

Arlinda Ymeraj, "The role of Social Protection to social exclusion and social capital" Robert MacNamara Fellowship Program, 1999

CIGO, "Urgent Rehabilitation of Schools and Prisons in Albania", July 1998

NACSS, Paper, "Social Assistance and Welfare in Albania", May 1999

Council of Ministers, Department of Development and Foreign Aid Coordination, "Public Investment Program" 1996-1998

Brian Munday \& George Lane, "The old and new. Changes in social care in Central and Eastearn Europe "Eissa, 1998

Albanian National Observatory "Albanian National Observatory national report" 1997

Albanian National Observatory "Albanian National Observatory national report" 1999

UNDP, Human Development Report, 1998

Ministry of Labour and Social Affairs, Statistics, 1999

Ministry of Labour and Social Affairs, Statistics semiannually, 2000

Ministry of Health, "Evaluation of primary health service" analysis report statistics conducted by IMC in collaboration with the Ministry of Health, Tirana 1999

Statistics Monthly Statistical Bulletin 3. No.4 Tirana 1999.

Albanian Ministry of Health "Health Care Reform in Albania", Background Document No.1 'Situation analysis' Tirana 1996

Ministry of Health, Department of Statistics and Information, Tirana 2000

Ministry of Health, Department of Health Education, 'Guidelines on vaccinations, Tirane 1999.

Ministry of Education, 1999-2000 Statistics,

INSTAT, Social indicators by region, 2012 